\title{
«ОРУ ДИЕ И ЗНАК В РАЗВИТИИ РЕБЕНКА»: САМАЯ ИЗВЕСТНАЯ РАБОТА Л.С. ВЫГОТСКОГО, КОТОРУЮ ОН НИКОГДА НЕ ПИСАЛ
}

\author{
А. ЯСНИцКИЙ
}

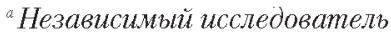

\section{Резюме}

В статье рассматривается непростая история создания, многократного перевода, фальсификации и публикации (под названием «Орудие и знак в развитии ребенка») одного текста Выготского и Лурии, признанного впоследствии одной из основополагающих работ Выготского. Данное исследование прослеживает путь этого текста от его первой версии (предположительно созданной в конце 1920-х гг.) к машинописной версии текста на английском языке, переданной Лурией М. Коулу для публикации за границей в начале $1970-\mathbf{x} г$ г, и, наконец, к русской версии текста, переведенной с английской машинописи обратно на русский язык, когда оригинальная версия русского текста была утрачена. Исследование было проведено на материале сравнительного структурного и текстологического анализа работы и ее повторяющихся фрагментов (т.е. небуквальных смысловых повторов как в русском тексте, так и в его различных вариациях на русском и английском языках), а также в результате обращения к архивным документам и мемуарным публикациям. Данная статья демонстрирует, что русский текст «Орудие и знак», впервые опубликованный на русском языке в 1984 г. под редакцией М.Г. Ярошевского, был создан в результате манипуляций с текстом, вызванных нескоординированной работой двух (или более) переводчиков и, вероятно, редакторской правкой. В результате анализа автор приходит к выводу, что доверие к русскоязычному тексту, опубликованному издательством «Педагогика» в 1984 г. в шестом томе собрания сочинений Выготского, как к аутентичному тексту Выготского (и Лурии) начала 1930-х гг. окончательно подорвано. В заключение в статье обсуждаются вопрос возможной датировки этого текста и проблема аутентичности в современном ревизионистском выготсковедении.

Ключевые слова: Выготский, Ярошевский, цензура, фальсификация, текстология, сравнительный анализ, архив, мемуары, «Орудие и знак».

Автор выражает свою признательность Н. Кременцову (Nikolai Krementsov, Canada) за вдохновение и консультации по различным вопросам истории науки, Р. ван дер Beepy (René van der Veer, Нидерланды), А. Тоомела (Aaro Toomela, Эстония), О. Носковой и М. Фаликман (Olga Noskova \& Maria Falikman, РФ) за обсуждение ранних вариантов этой статьи, Д. Келлоггу (David Kellogg, Корея/Австралия), Л. Мекаччи (Luciano Mecacci, Италия), Л. Сэву (Lucien Sève, Франция), П. Кайлеру (Peter Keiler, Германия) и Е. Матусову (Eugene Matusov, США) за сообщения о ценных текстологических находках. Отдельное спасибо Е. Завершневой (Ekaterina Zavershneva, PФ) за консультации и сотрудничество. При подготовке этой статьи использованы материалы публикаций в «Психологическом журнале Международного университета природы, общества и человека "Дубна” (PsyAnima, Dubna Psychological Journal), см. обзор в Интернете: http://psyanimajournal.livejournal.com/9491.html 
I guess you think you know this story. You don't. The real one's much more gory.

The phoney one, the one you know,

Was cooked up years and years ago,

And made to sound all soft and sappy, Just to keep the children happy.

Roald Dahl, Cinderella ${ }^{1}$

Эта история имеет все зачатки лихо закрученного политического детектива, кроме, пожалуй, собственно преступления: здесь есть и рукопись, и загадка, и международные сети агентов, и расшифровка тайных умыслов и смыслов, и заграничная переписка времен холодной войны, есть даже уже и тысячи поклонников по всему миру и всемирная слава. У этой истории нет только автора, а потому она пока что остается нерассказанной. А мы тем временем приведем лишь основные факты, как они предстают для нас сейчас.

\section{«Орудие и знак»: транснациональная история утерянной рукописи и ее странной публикации}

Первое упоминание о совместной работе Л.С. Выготского (1896-1934) и А.Р. Лурии (1902-1977) над «большой главой» про орудия и знаки в развитии ребенка мы находим в част ном письме от 15 февраля 1931 г. Лурии его американскому другу профессору философии из престижного нью-йоркского университета Новая школа социальных исследований (The New School for Social Research) Хорасу M. Каллену (Horace M. Kallen; 1882-1974)². В этом письме, рассказывая о незадолго до этого проведенной работе, Лурия пишет о совместной главе, названной «Tools and signs in the development of the child» и написанной для публикации на английском языке в Соединенных Штатах в сборнике работ по детской психологии «Handbook of child psychology» под редакцией профессора, издателя и научного антрепренера Карла Мерчисона (Carl Murchison; 1887-1961). И вправду, сборник под таким названием вышел в 1931 г. в издательстве Кларкского университета (Murchison, 1931), но работы Выготского и Лурии в нем по той

\footnotetext{
Этими строками начинается стихотворение английского писателя, классика детской литературы Роальда Даля «Синдерелла», в котором автор в несколько ироничной форме подвергает радикальному пересмотру каноническую версию сюжета о Синдерелле (Золушке) и предлагает свою версию истории, пересказанную в сатирическом ключе и с элементами черного юмора.

${ }^{2}$ Письмо Лурии, равно как и часть их обширной переписки с Калленом, хранится в American Jewish Archives [AJA] (The Jacob Rader Marcus Center of the American Jewish Archives at the Hebrew Union College-Jewish Institute of Religion [HUC-JIR]), Cincinnati, OH: Horace M. Kallen Papers.
} 
или иной причине не оказалось. Этот текст, по утверждению автора письма, послужил своего рода обобщающей работой, основанной на недавней серии исследований, проведенных авторами главы и их сотрудниками в области детского «культурного развития». В заключение автор письма просил своего уважаемого коллегу, мнением которого он, по его заверению, очень дорожил, высказаться по поводу этой совместной работы ${ }^{3}$. Ответа адресата письма на эту просьбу пока что нам обнаружить не удалось.

Впервые на русском языке рукопись «Орудие и знак», датированная 1930 г., была упомянута в библиографии работ Выготского 1934 г. в разделе книг по психологии (Выготский, 1934, с. 321$)^{4}$. В том же самом документе фигурирует и совместная рукопись Выготского и Лурии под названием «Tool and symbol in the development of the child» («Орудие и знак в развитии ребенка»), также датированная 1930 г., при этом с особым указанием «направлено в "Handbook of Child-Psychology"» (Там же, с. 323) (см. таблицу 1$)^{5}$.

После этого на протяжении нескольких десятилетий мы практически ничего не знали ни о русской, ни об английской версии данного текста вплоть до 1976 г., когда впервые в советских публикациях послевоенного периода упоминание этой работы появилось в книге В.В. Иванова, вышедшей в издательстве «Наука» под названием «Очерки по истории семиотики в СССР» (Иванов, 1976) ${ }^{6}$. Обсуждение этого любопытного эпизода см. ниже.

${ }^{3}$ В оригинале на немецком языке (авторская орфография и пунктуация переданы без изменений): «Das letzte, was wir zusammen mit ihm machten, war ein grosseres Kapittel in Murchison's "Handbook of Child Psychology"; das Kapittel hat den Titel "Tools and Signs in the development of the Child" und ist eine Zusammenfassung unserer letzten Arbeiten, die mit der Kulturentwickelung des Kindes zu tun haben. Ich wahre ausserordentlich froh, wenn Sie den Aufsatz lesen und mir darüber schreiben möchten, - Sie wissen ja wie hoch ich Ihre Meinung schätze».

${ }^{4}$ См. бнблиографию работ Выготского из его книги «Мышление и речь» в Интернете по адресу http://psychlib.ru/mgppu/VMr-1934/VMR-001.НTM\#Перечень_работ_проф_Л_С__ Выготского; ссылки на значительную и постоянно растущую коллекцию работ Выготского, бесплатно доступных для скачивания в виде отсканированных первых изданий оригинальных текстов см. также в Интернете по адресу: http://psyanimajournal.livejournal.com/3526.html.

${ }^{5}$ И в письме Лурии Каллену за февраль 1931 г., и в ссылке на несостоявшуюся английскую публикацию этой работы в оригинальном издании книги «Мышление и речь» (1934) указано соавторство двух исследователей - Выготского и Лурии, - восстановленное при публикации әтого текста в сборнике работ «круга Выготского» в 1994 г. (Vygotsky, 1994). В свете этого обстоятельства, а также всей той несомненно значительной редакторской работы, которую Лурия провел между 1930 г., когда текст был написан, и концом 1960-х, когда началась подготовка текста к печати (см.: Гольдберг, 2012; Коул, 2012; Cole, 2012; Goldberg, 2012), можно, пожалуй, утверждать, что соавторство Лурии в известных нам текстах этой работы сомнению не подлежит.

${ }^{6}$ Полный текст книги доступен в Интернете, например, на сайте Института славяноведения PAH; см. источник по адресу: http://www.inslav.ru/resursy/elektronnaya-biblioteka/2071-1976ivanov; cм. также: http://philologos.narod.ru/semiotics/ivanov_semio.htm. 
Затем, всего два года спустя, в 1978 г. в издательстве Гарвардского университета вышла другая книга, которой - к большому удивлению издателей и вопреки самым оптимистичным прогнозам команды ее редакторов под неформальным руководством Майкла Коула (Michael Cole) - суждено было ознаменовать собой начало явления, называемого разными авторами то «бум» (Vygotsky boom) (Коул, 2012; Cole, 2004, 2012; Garai, Kocski, 1995), то «революция» (Vygotskian revolution) (Harre, 2006), а то и «культ Выготского» (the cult of Vygotsky) (Yasnitsky, 2010, 2011).

Эта книга, вышедшая под именем Выготского и под названием «Mind in society. The development of higher psychological processes» (Vygotsky, 1978), по признанию ее редакторов, была «сконструирована» ${ }^{7}$ из разных текстов Выготского, которые А.Р. Лурия передал Майклу Коулу для публикации на Западе. Основу первой половины этой книги, по утверждению ее редакторов, как раз и составила рукопись неопубликованной работы 1930 г. «Tool and symbol in children's development», из материалов которой были «построены» главы с первой по четвертую «Mind in society» (Cole et al., 1978, p. ix). Работа над подготовкой этой рукописи к печати и роль Лурии и Коула в последующей публикации этого текста отражены в ряде работ (Коул, 2012; Cole, 2012), а образцы страниц машинописного документа на английском языке с рукописной правкой Лурии и его американских коллег-соредакторов приведены ван дер
Веером (ван дер Веep, 2012; Van der Veer, 2012).

Вскоре, в 1984 г., текст этой работы был опубликован на русском языке под редакцией М.Г. Ярошевского в шестом томе собрания сочинений Выготского, но не под названием «Орудие и знак», под которым она изначально фигурировала в библиографии работ Выготского, приведенной в конце книги «Мышление и речь» 1934 г., а в расширенном варианте английской версии названия «Орудие и знак в развитии ребенка» (Выготский, 1984).

Десять лет спустя, в 1994 г., в хрестоматии «The Vygotsky reader» ван дер Веер и Валсинер опубликовали полный текст той английской версии машинописи, которую Майкл Коул изначально получил от Лурии и передал для первой полной публикации на английском языке редакторам хрестоматии. Эта публикация 1994 г. вышла под названием «тоо and symbol in child development» (Vygotsky, 1994; см. краткую предысторию этой публикации приводит: ван дер Beep, 2012; Van der Veer, 2012).

Наконец, в 1999 г. вышла еще одна версия текста на английском языке: в шестом томе переводного издания русского шеститомника издательства «Педагогика» был опубликован перевод русского текста 1984 г. под названием «Tool and sign in the development of the child» (Vygotsky, 1984/1999). Таким образом, примечательным выглядит уже тот факт, что ни в одном из этих изданий название текста ни разу не повторяется, причем слову «знак» в

\footnotetext{
${ }^{7}$ Дословно в оригинале: «constructed».
} 
русских изданиях неизменно соответствует слово «symbol» во всех английских изданиях, кроме последнего, где это слово передано как «sign», что следует считать более адекватным переводом (Vygotsky, 1984/ 1999) (см. таблицу 1)

Также обращает на себя внимание то обстоятельство, что многостраничный текст работы «Орудие и знак в развитии ребенка», вышедшей на русском в 1984 г. (85 страниц) и на английском языке в 1994 г. (72 страницы), по своему объему более чем вдвое превышает средний объем главы в сборнике Мерчисона 1931 г. $^{8}$ Тем не менее трудно сказать, тот ли это вариант текста, что был предположительно отправлен для публикации в США в 1930 г.: мы можем лишь предположить, что в таком виде, как мы знаем его сейчас, этот текст вряд ли мог быть напечатан тогда в том издании.

\section{«Орудие и знак»: наброски к анализу текста}

История этих рукописей загадочна, а разгадка тайны их происхождения и перемещения по планете может составить тему отдельного, самостоятельного исследования. Тем не менее данная работа интересна не только по этой причине. Сам текст «Орудие и знак в развитии ребенка» представляет собой загадку чуть ли не меньшую, чем его история. Итак, посмотрим, в чем же эта загадка.

В первую очередь, сравнение опубликованных русской (1984) и английской (1994) версий текста показывает, что русский текст несколько длиннее, чем его английский аналог. При этом примечательно то, что русская версия длиннее за счет лишь отдельных секций и глав, в то время как другие главы по своей длине вполне сопоставимы с английским текстом (см. рисунок 1).

Таблица 1

Генеалогия названий рукописи и публикаций работы «Орудие и знак»

\begin{tabular}{|c|l|l|}
\hline & \multicolumn{1}{|c|}{ По-русски } & \multicolumn{1}{c|}{ По-английски } \\
\hline 1931 & - & $\begin{array}{l}\text { Tools and signs in the development of the } \\
\text { child }\end{array}$ \\
\hline 1934 & Орудие и знак (рукопись) & $\begin{array}{l}\text { Tool and symbol in the development of the } \\
\text { child }\end{array}$ \\
\hline 1976 & $\begin{array}{l}\text { Орудие и знак в развитии ребенка } \\
\text { (архив Л.С. Выготского })\end{array}$ & - \\
\hline 1978 & & Tool and symbol in children's development \\
\hline 1984 & Орудие и знак в развитии ребенка & - \\
\hline 1994 & - & Tool and symbol in child development \\
\hline 1999 & - & Tool and sign in the development of the child \\
\hline
\end{tabular}

\footnotetext{
${ }^{\circledR}$ Ср. общий объем «Handbook of child psychology» (1931) - 22 главы, 688 страниц текста.
} 
Рисунок 1

Сравнительная длина (в страницах) русского (1984) и английского (1994) изданий работы «Орудие и знак»

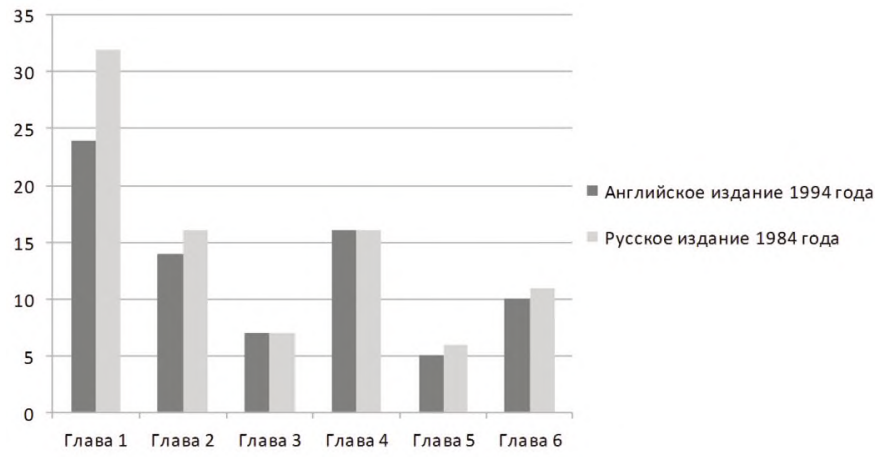

Обращают на себя внимание различия в длине текста глав 1, 2, 5 и 6 этих двух изданий. И если длины глав 3 и 4 идентичны, а глав 5 и 6 текста на русском и английском языках различаются лишь на одну страницу, что можно списать на различия в шрифте, наборе и расположении текста на странице, то разные версии первых двух глав по длине различаются более существенно: соответственно на 8 и 2 страницы. Анализ размеров подглавок этих глав выявляет наиболее проблемные места. Так, раздел первой главы, «Эксперименты по практическому интеллекту ребенка», размещенный на 13 страницах текста в русском издании, соответствует лишь 7 страницам английского текста. Сходным образом раздел второй главы, «Произвольная структура высттих психических функций», в русском издании располагается на 4 страницах, а в английской версии - на 2 страницах (см. подробности в таблице 2).

Стоит упомянуть о том поразительном обстоятельстве, что, как выяснилось в ходе подготовки публикации английской версии текста и сверки рукописи с опубликованной советской версией этой работы, «русская версия 1984 г. содержит несколько страниц, которые слово в слово повторяют фрагменты текста, идущего ниже. Наиболее вероятно, что эти повторы появились в результате редакторских манипуляций с текстом в 1970-1980-x» (Van der Veer, Valsiner, 1994, p. 171; см. также: ван дер Веep, 2012; Van der Veer, 2012). Ван дер Веер и Валсинер установили текстуальные соответствия в главах 1 (с. 14-17) и 4 (с. 69-72 и c. 74-75) русского издания. Ср. попарно такие параллельные фрагменты в таблице 3.

Еще одну серию текстуальных повторов, чуть ли не зеркально отражающих текст конца второй и начала третьей глав русской публикации «Орудие и знак», обнаружил Дэвид Келлогг в ходе подготовительной работы над первым переводом этого текста на корейский язык (Kellogg, 2011; Kellogg, Yasnitsky, 2011). Bce эти повторяющиеся фрагменты русского текста в сравнении с параллельным английским текстом см. на рисунке 2. 
Таблица 2

Сравнительное оглавление и длина публикации: «Tool and symbol» (1994) и «Орудие и знак» (1984)

\begin{tabular}{|c|c|c|c|c|c|}
\hline \multicolumn{3}{|c|}{ Tool and symbol (1994) } & \multicolumn{3}{|c|}{ Орудие и знак (1984) } \\
\hline Chapter/Глава & $\begin{array}{l}\text { Pages, } \\
\text { Figures/ } \\
\text { Стр., } \\
\text { Рис. }\end{array}$ & $\begin{array}{l}\text { Length/ } \\
\text { Длина }\end{array}$ & Chapter/Глава & $\begin{array}{l}\text { Pages/ } \\
\text { Стр. }\end{array}$ & $\begin{array}{l}\text { Length/ } \\
\text { Длина }\end{array}$ \\
\hline $\begin{array}{l}\text { 1. The problem of the practical } \\
\text { intelligence in animal and } \\
\text { child }\end{array}$ & $99-122$ & 24 & $\begin{array}{l}\text { Глава первая. Проблема } \\
\text { практического интеллекта в } \\
\text { психологии животных и } \\
\text { психологии ребенка }\end{array}$ & $6-37$ & 32 \\
\hline $\begin{array}{l}\text { Experiments on the practical } \\
\text { intelligence of the child }\end{array}$ & $100_{-}$ & 7 & $\begin{array}{l}\text { Эксперименты по } \\
\text { практическому интеллекту } \\
\text { ребенка }\end{array}$ & $7-$ & 13 \\
\hline $\begin{array}{l}\text { The function of speech in tool } \\
\text { use: the problem of practical } \\
\text { and verbal intelligence }\end{array}$ & $106-$ & & $\begin{array}{l}\text { Функция речи в } \\
\text { употреблении орудия. } \\
\text { Проблема практического и } \\
\text { вербального интеллекта }\end{array}$ & $19-$ & \\
\hline $\begin{array}{l}\text { Speech and action in child } \\
\text { behaviour }\end{array}$ & $108-$ & & $\begin{array}{l}\text { Речь и практическое } \\
\text { действие в поведении } \\
\text { ребенка }\end{array}$ & $21-$ & \\
\hline $\begin{array}{l}\text { The development of the child's } \\
\text { higher forms of practical activi- } \\
\text { ty }\end{array}$ & $112-$ & & $\begin{array}{l}\text { Развитие высших форм } \\
\text { практической деятельности у } \\
\text { ребенка }\end{array}$ & $26-$ & \\
\hline $\begin{array}{l}\text { Development in the light of } \\
\text { facts }\end{array}$ & $115-$ & & Путь развития в свете фактов & $29-$ & \\
\hline $\begin{array}{l}\text { The function of socialized and } \\
\text { egocentric speech }\end{array}$ & $118-$ & & $\begin{array}{l}\text { Функция социализированной } \\
\text { и эгоцентрической речи }\end{array}$ & $32-$ & \\
\hline $\begin{array}{l}\text { The change of the function of } \\
\text { speech in practical operation }\end{array}$ & $120-$ & & $\begin{array}{l}\text { Изменение функции речи в } \\
\text { практической деятельности }\end{array}$ & $34-$ & \\
\hline $\begin{array}{l}\text { 2. The function of signs in the } \\
\text { development of higher psycho- } \\
\text { logical processes }\end{array}$ & $122-135$ & 14 & $\begin{array}{l}\text { Глава вторая. Функция } \\
\text { знаков в развитии высших } \\
\text { психических процессов }\end{array}$ & $37-52$ & 16 \\
\hline $\begin{array}{l}\text { The development of higher } \\
\text { forms of perception }\end{array}$ & $123-$ & & $\begin{array}{l}\text { Развитие высших форм } \\
\text { восприятия }\end{array}$ & $38-$ & \\
\hline $\begin{array}{l}\text { The separation of the primary } \\
\text { umity of the sensory-motor } \\
\text { functions }\end{array}$ & $127-$ & & $\begin{array}{l}\text { Разделение первичного } \\
\text { единства сенсомоторных } \\
\text { функций }\end{array}$ & $41-$ & \\
\hline $\begin{array}{l}\text { The reorganization of the func- } \\
\text { tions of memory and attention }\end{array}$ & $132-$ & & $\begin{array}{l}\text { Перестройка памяти и } \\
\text { внимания }\end{array}$ & $47-$ & \\
\hline $\begin{array}{l}\text { The voluntany structure of the } \\
\text { higher psychological functions }\end{array}$ & $134-$ & 2 & $\begin{array}{l}\text { Произвольная структура } \\
\text { высших психических } \\
\text { функций }\end{array}$ & $49-$ & 4 \\
\hline
\end{tabular}


Таблица 2 (окомиание)

\begin{tabular}{|c|c|c|c|c|c|}
\hline \multicolumn{3}{|c|}{ Tool and symbol (1994) } & \multicolumn{3}{|c|}{ Орудие и знак (1984) } \\
\hline Chapter/Тлава & $\begin{array}{l}\text { Pages, Figures/ } \\
\text { Стр., Рис. }\end{array}$ & $\begin{array}{l}\text { Length/ } \\
\text { Длина }\end{array}$ & Chapter/Глава & $\begin{array}{c}\text { Pages/ } \\
\text { Стр. }\end{array}$ & $\begin{array}{r}\text { Length/ } \\
\text { Длина }\end{array}$ \\
\hline $\begin{array}{l}\text { 3. Sign operations and the } \\
\text { organization of the psycho- } \\
\text { logical processes }\end{array}$ & $135-141$ & 7 & $\begin{array}{l}\text { Глава третья. Знаковые } \\
\text { операции и } \\
\text { организация } \\
\text { психических процессов }\end{array}$ & $53-59$ & 7 \\
\hline $\begin{array}{l}\text { Problems of signs in the for- } \\
\text { mation of the higher psycho- } \\
\text { logical functions }\end{array}$ & $135-$ & & $\begin{array}{l}\text { Проблема знака в } \\
\text { формировании высших } \\
\text { психических функций }\end{array}$ & $53-$ & \\
\hline $\begin{array}{l}\text { The social genesis of the high- } \\
\text { er psychological functions }\end{array}$ & $137-$ & & $\begin{array}{l}\text { Социальный генез } \\
\text { высших психических } \\
\text { функций }\end{array}$ & $55-$ & \\
\hline $\begin{array}{l}\text { The main mules of development } \\
\text { of the higher psychological } \\
\text { functions }\end{array}$ & $\begin{array}{l}\quad 138- \\
\text { fig. } 1, \text { p. } 140\end{array}$ & & $\begin{array}{l}\text { Основные правила } \\
\text { развития высших } \\
\text { психических функций }\end{array}$ & $56-$ & \\
\hline $\begin{array}{l}\text { 4. The analysis of sign opera- } \\
\text { tions in the child }\end{array}$ & $141-156$ & 16 & $\begin{array}{l}\text { Глава четвертая. } \\
\text { Анализ знаковых } \\
\text { операций ребенка }\end{array}$ & $60-75$ & 16 \\
\hline The structure of sign operation & $\begin{array}{l}142- \\
\text { fig. } 2, \text { p. } 144\end{array}$ & & $\begin{array}{l}\text { Структура знаковой } \\
\text { операции }\end{array}$ & $61-$ & \\
\hline $\begin{array}{l}\text { The genetic analysis of sign } \\
\text { operation }\end{array}$ & $\begin{array}{l}\quad 147- \\
\text { fig. } 3 \& 4, \text { p. } 149 \\
\text { fig. } 5 \text {, p. } 150\end{array}$ & & $\begin{array}{l}\text { Генетический анализ } \\
\text { знаковой операции }\end{array}$ & $65-$ & \\
\hline $\begin{array}{l}\text { The further development of } \\
\text { sign operations }\end{array}$ & $152-$ & & $\begin{array}{l}\text { Дальнейшее развитие } \\
\text { знаковых операций }\end{array}$ & $70-$ & \\
\hline $\begin{array}{l}\text { 5. Methods for the study of } \\
\text { higher psychological func- } \\
\text { tions }\end{array}$ & $157-161$ & 5 & $\begin{array}{l}\text { Глава пятая. Методика } \\
\text { изучения высших } \\
\text { психических функций }\end{array}$ & $75-80$ & 6 \\
\hline 6. Conclusions & $161-170$ & 10 & $\begin{array}{l}\text { Заключение. Проблема } \\
\text { функциональных } \\
\text { систем }\end{array}$ & $80-90$ & 11 \\
\hline $\begin{array}{l}\text { The problem of functional sys- } \\
\text { tems }\end{array}$ & $161-$ & & & & \\
\hline $\begin{array}{l}\text { The use of tools in animal and } \\
\text { human behaviour }\end{array}$ & $164-$ & & $\begin{array}{l}\text { Употребление орудий у } \\
\text { животного и человека }\end{array}$ & $83-$ & \\
\hline Word and action & $166-170$ & & Слово и действие & $86-90$ & \\
\hline
\end{tabular}


Параллельные дублирующиеся фрагменты в тексте русского издания «Орудие и знак» 1984 г. (Выготский, 1984)

\begin{tabular}{|c|c|}
\hline $\begin{array}{r}\text { Первое появле } \\
\text { глав }\end{array}$ & $\begin{array}{c}\text { Второе появление фрагмента в тексте, } \\
\text { глава } 4 \text { (с. } 69-72 \text { и с. } 74-75)\end{array}$ \\
\hline $\begin{array}{l}\text { Начало фрагмента 1: «Изучение } \\
\text { употребления знаков у ребенка и развития } \\
\text { этой операции с необходимостью привело нас } \\
\text { к исследованию того, как возникает, откуда } \\
\text { берет начало символическая деятельность } \\
\text { ребенка». } \\
\text { Конец фрагмента 1: «Отнести овладение } \\
\text { связью между знаком и значением к самому } \\
\text { началу культурного развития ребенка - } \\
\text { значит игнорировать сложнейшую, } \\
\text { растянутую более чем на целое десятилетие } \\
\text { историю внутреннего построения этой связи» } \\
\text { (с. 14-15). }\end{array}$ & $\begin{array}{l}\text { zмента 1': «Изучая } \\
\text { ие знака ребенком и } \\
\text { й деятельности, мы с } \\
\text { ью пришли к исследованию } \\
\text { никает знаковая } \\
\text { ». } \\
\text { иента 1': «Относить } \\
\text { им отношением к самому } \\
\text { урного развития ребенка - } \\
\text { ировать сложную историю } \\
\text { формирования отношения, } \\
\text { орая длится более } 10 \text { лет» }\end{array}$ \\
\hline $\begin{array}{l}\text { цифическое } \\
\text { особыми }\end{array}$ & $\begin{array}{l}\text { вращива- } \\
\text { ий внутрь...» } \\
\text { e } \\
\text { имеющее } \\
75 \text { ). }\end{array}$ \\
\hline $\begin{array}{l}\text { Начало фрагмента 3: «Этот перенос } \\
\text { социального способа поведения в систему } \\
\text { индивидуальных приспособлений опять-таки } \\
\text { не является чисто механическим...» } \\
\text { Конеи фрағмента 3: «..еще не оторвалась от } \\
\text { внешней деятельности, еще не } \\
\text { эмансипировалась от наглядного восприятия } \\
\text { и внешнего действия (например, наглядное, } \\
\text { или практическое, мышление ребенка)» } \\
\text { (с. 16-17). }\end{array}$ & $\begin{array}{l}\text { Начало фрагмента 3': «Перенос } \\
\text { социальных способов поведения внутрь } \\
\text { системы индивидуальных форм } \\
\text { приспособления вовсе не есть чисто } \\
\text { механический перенос...» } \\
\text { Комеи фрагмента 3': «...ее не } \\
\text { выделены из внешней деятельности, не } \\
\text { обособлены от непосредственного } \\
\text { восприятия и внешнего действия, } \\
\text { например практического мышления } \\
\text { ребенка» (с. } 71-72) .\end{array}$ \\
\hline
\end{tabular}

Таким образом, как мы видим (рисунок 2), целый ряд небуквальных повторов текста, опубликованного на с. 151-156 английского издания, встречается в двух местах русского текста: на с. 69-75 в буквально том же порядке и в тех же местах, что и в английском тексте, а с другой стороны, еще и на с. 14-17, при этом порядок следования разных сегментов текста по сравнению с англий- ским изданием несколько нарушен. В то же время в соответствующем месте английского издания на с. 106 и в ее окрестностях этот текст отсутствует.

Несколько иначе собраны конец главы 1 - начало главы 2. Так, фрагмент на с. 126-127 английского издания не встречается в соответствующем месте русского текста, где в качестве единственного упоминания 
Рисунок 2

Параллельные и повторяющиеся фрагменты текста в советском издании 1984 г. в сравнении с англоязычным изданием 1994 г. Непрерывные линии означают текстовые повторы, прерывистыми линиями в сочетании с крестообразными фигурами на осях обозначены ожидаемые, но не наблюдаемые соответствия английского и русского текста

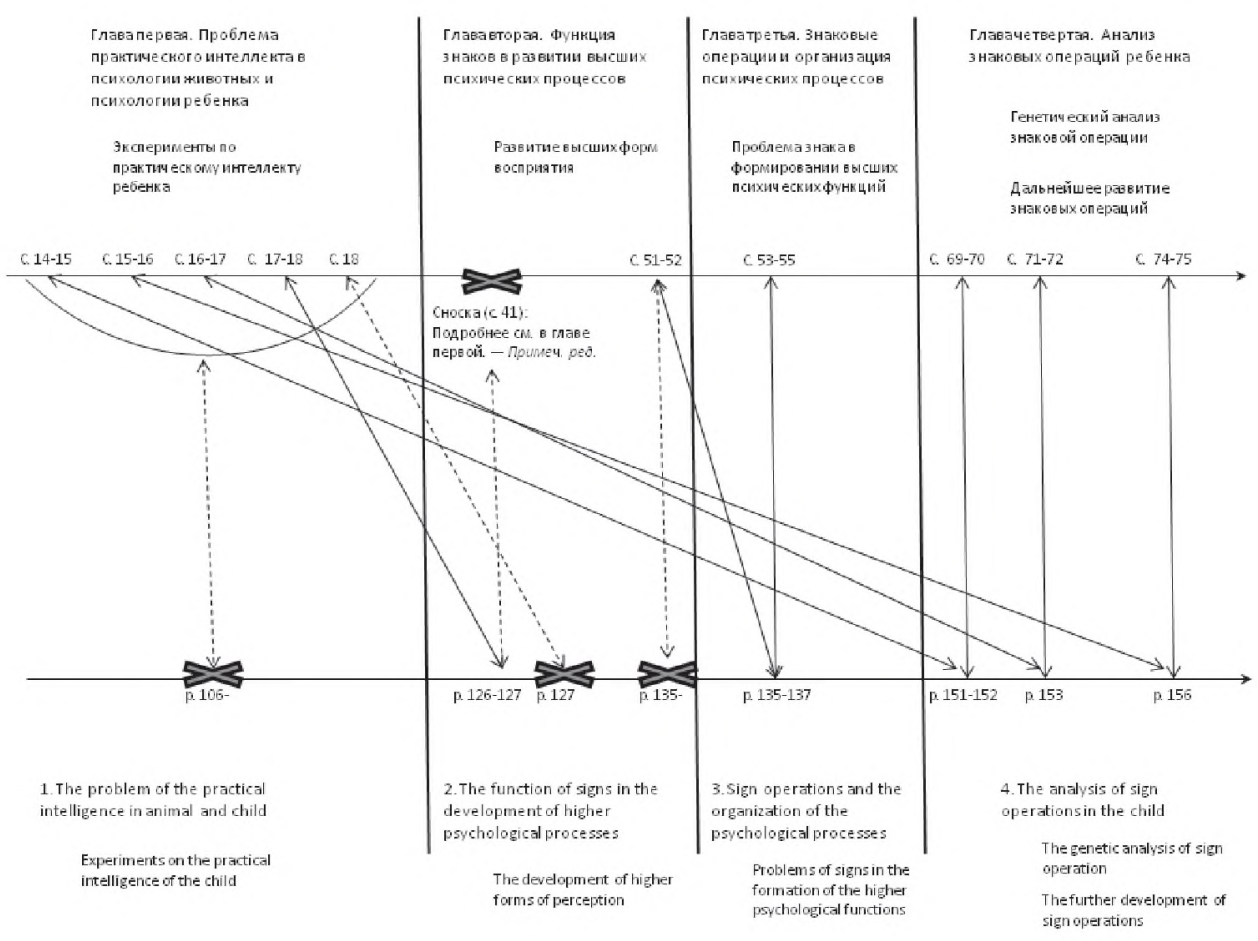

о текстовой лакуне можно найти лишь редакторскую сноску следующего содержания: «Подробнее см. в главе первой. - Прим. ред.» (напоминаем, редактор тома 6 собрания сочинений Выготского - М.Г. Ярошевский). И вправду, этот фрагмент из начала второй главы английского текста (c. 126-127) действительно встречается на с. 17-18 в конце первой главы русского текста. Интересно при этом, что фрагмент текста, последовавший за этим, условно говоря, «перемещенным» фрагментом на с. 18 русского издания, в анг- лийском тексте обнаружить нигде не удалось.

Еше более странно выглядят концовка второй (абзацы 52-58 на c. 51-52) и начало третьей главы (абзацы 3-7 на с. 53-55). Происходящее здесь наиболее, пожалуй, приближенно к реальности можно описать в терминах «зеркального отображения». Это значит, что зачастую абзацы текста, стоящие в самом конце главы 2, первыми появляются в начале текста главы 3. Некоторые пары абзацев конца главы 2 (56 и 57, а также 54 и 58) в главе 3 опублико- 
ваны одним абзацем (соответственно абзацы 3 и 4). Здесь мы опять же имеем дело с фактическим, но не буквальным повтором текста. Детали см. на рисунке 3.

Мы признательны как ван дер Вееру и Валсинеру, так и Келлоггу за указание на повторяющиеся фрагменты текста «Орудие и знак» издания 1984 г. И в то же время следует обратить самое пристальное внимание не столько на черты сходства этих бесспорно одинаковых фрагментов, сколько на черты различия между ними, наводящие нас на мысль о том, что дупликация фрагментов текста возникла не в результате, скажем, типографской оплошности, а, скорее, вследствие серьез- ных ошибок, допущенных в ходе редакторской работы.

Более того, сравнительный анализ этих фрагментов позволяет нам со всей решительностью сформулировать рабочую гипотезу их происхождения, которая, разумеется, еще нуждается в подтверждении (или, напротив, опровержении). Согласно предположению, высказанному еще в 1991 г. во всемирно известной классической книге ван дер Веера и Валсинера «Understanding Vygotsky. A quest for synthesis», все эти тексты появились на свет в результате перевода на русский язык предположительно какой-то английской версии этой работы (Van der Veer, Valsiner, 1991, p. 188).

Pucyнox 3

Параллельные и повторяющиеся фрагменты текста в конце второй и начале третьей главы в советском издании 1984 г.

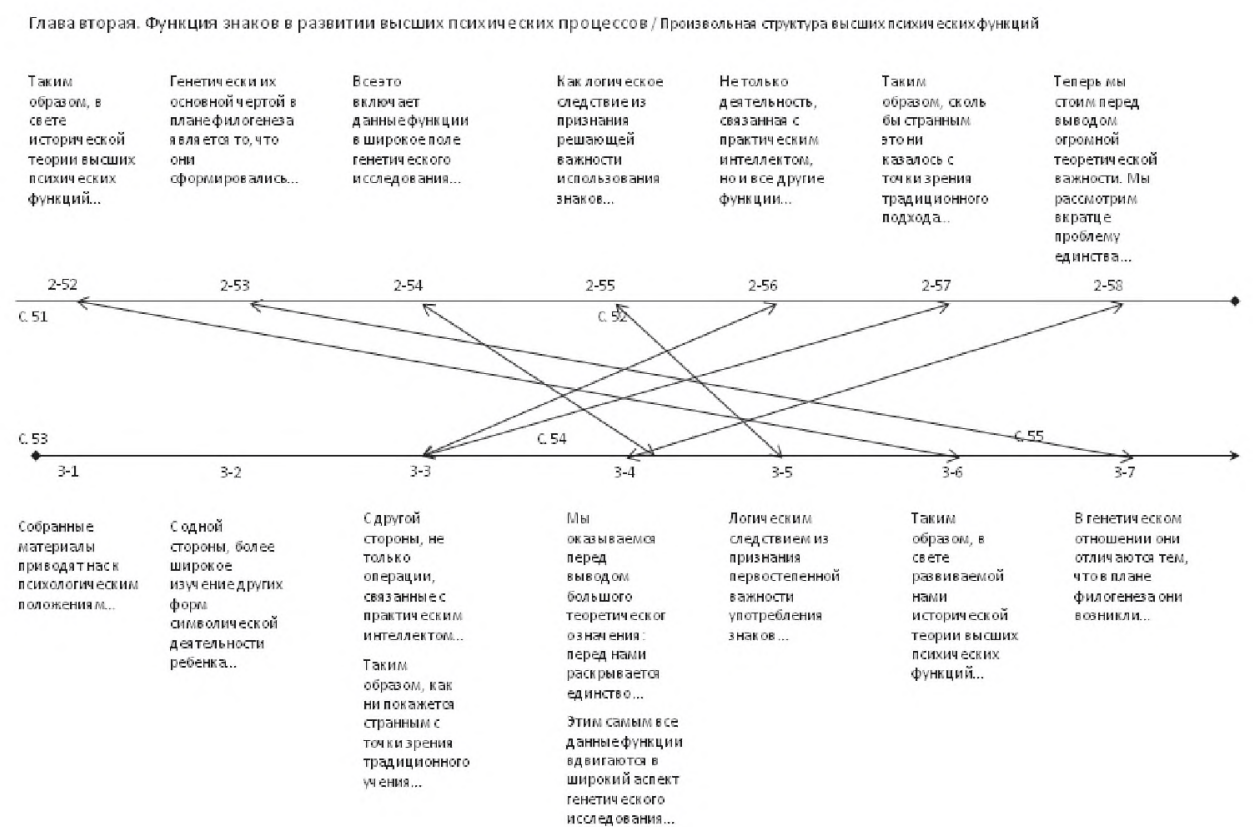


Предположение о публикации перевода с английского на русский нашло подтверждение в книге Эльхонона Гольдберга, который рассказывает предысторию появления на свет русской версии «Орудия и знака» в том виде, в каком мы знаем этот текст по публикации в издательстве «Педагогика», вышедшей в 1984 г. В своей сравнительно недавней книге «Тhe wisdom paradox: how your mind can grow stronger as your brain grows older» Гольдберг, в прошлом близкий ученик и сотрудник Лурии, сообщает, что в конце 1960-х гг., когда возникла идея опубликовать «Орудие и знак» в Советском Союзе, Лурия обнаружил, что оригинальный русский текст утрачен. Выход в этой, казалось бы, отчаянной ситуации был найден: английская версия работы сохранилась, и, к несказанному изумлению Гольдберга, Лурия дал тому задание сделать обратный перевод с английского на русский, максимально похоже на оригинальный текст Выготского и Лурии, что и было исполнено. По выражению Гольдберга, их «невинная подделка» (benign forgery) была выдана за оригинальный текст и украшает собой один из томов шеститомного собрания сочинений Выготского без разъяснения того, что же на самом деле предшествовало этой публикации (Goldberg, 2005, р. 99). (Более подробно об истории и эволюции взаимоотношений Гольдберга и Лурии см.: Goldberg, 2001, 2009.) В своей книге Гольдберг датирует «обратный перевод» концом 1960-х. Действительно, решение о публикации многотомного собрания сочинений Выготского было предположительно принято в 1966 г. на уровне Президиума Академии педагогических наук (АПН) РСФСР (Выгодская, Лифанова, 1996, с. 350-351) ${ }^{9}$. Таким образом, с учетом того, что в 1974 г. Гольдберг эмигрировал из Советского Союза, мы можем с определенной уверенностью датировать события его истории обратного перевода текста Выготского и Лурии на русский язык интервалом 1966-1974 гг. И вправду, в своей публикации, вышедшей в начале 2012 г. в «сихологическом журнале Международного университета природы, общества и человека “Дубна" » («PsyAnima, Dubna Psychological Journal») в рамках обсуждения этой «невинной подделки», Гольдберг определил время работы над обратным переводом - 1968-1969 гг. и представил своего рода документальное подтверждение такой датировки (Goldberg, 2012).

И все же эта история обратного перевода на русский, как бы сенсационно она ни выглядела, не объясняет ни дублирующихся фрагментов текста, ни определенных различий между ними. Между тем напрашивается такое, вполне рациональное и достаточно простое объяснение этого явления: дупликация очень близких, но не идентичных фрагментов могла возникнуть в результате, скажем, неслаженной работы двух (или более) переводчиков, работавших над переводом одного и того же английского текста на русский язык и затем ошибочного

${ }^{9}$ Постановлением ЦК КПСС и Совета министров СССР от 1 августа 1966 г. АПН РСФСР была преобразована в Академию педагогических наук СССР. 
сведе́ния этих двух переводов в один текст. Косвенное подтверждение эта версия находит в воспоминаниях анонимного блогера Ренатуса (Pенатус, 2012), а также в публикации Эльхонона Гольдберга с обсуждением этой версии Ренатуса (Гольдберг, 2012; Goldberg, 2012). Впоследствии автор, пожелавший сохранить свою анонимность на момент публикации текста в 2012 г. $^{10}$, раскрыл свое имя публично, сопроводив это «саморазоблачение» разьяснительным комментарием «текст взят публикаторами из моих рассылок». Автором оказался современный психолог, сотрудник психологического факультета МГУ А.А. Пузырей ${ }^{11}$. В подкрепление версии о существовании двух (или более) переводчиков, породивтиих близкие по смыслу, но не буквально идентичные переводы с английского языка, чуть дальше мы проведем иллюстративный сравнительный разбор двух таких сходных фрагментов текста (см. таблицу 4 и сопутствующее обсуждение ниже). Тем временем здесь необходимо несколько отвлечься на обсуждение вопроса датировки окончательной версии исходного русского текста, предположительно не допедшего до напих дней.

\section{Почему нельзя верить Ярошевскому: на подходах к датировке оригинальной работы}

Появившийся на свет в результате явных манипуляций и опублико- ванный под названием «Орудие и знак в развитии ребенка» текст традиционно датируется 1930 г. Так, например, составитель, автор послесловия и комментариев к шестому тому собрания сочинений Выготского, доктор психологических наук, профессор М.Г. Ярошевский (19152001) в своем комментарии к изданию текста «Орудие и знак в развитии ребенка» указывает следующее: «Работа написана Л.С. Выготским в 1930 г. Издается впервые по тексту рукописи. Содержит в концентрированном виде ряд основных положений культурно-исторической теории развития психики и прямо соотносится с такими работами Выготского, как “Мышление и речь”, “История развития высших психических функций”, “Инструментальный метод в психологии” и др.» (Ярошевский, 1984, с. 348).

У нас есть серьезные основания усомниться в правильности этой датировки и такой оценки роли и места этого текста среди других работ Выготского. Тому есть целый ряд причин.

Первое. Использованное Ярошевским выражение для обозначения теории Выготского, а именно «культурно-историческая теория развития психики», никогда не встречается ни в одном тексте самого Выготского. Точно так же не найти в прижизненно опубликованных текстах Выготского и другого выражения из цитаты Ярошевского: «высшие психиче-

${ }^{10}$ По его собственному выражению, автор предпочитал пуб́ликацию «под интернетовскими именами» или же «под гетеронимом» (из частной переписки, в письмах от 13 июня и 23 июля 2012 г. соответственно).

${ }^{11}$ См. в Интернете: http://istina.msu.ru/publications/article/6753539/. 
ские функции». Как показывает исследование Петера Кайлера, терминология и фразеология Выготского в целом ряде мест заметно отличаются от фразеологии, приписываемой ему. Так, например, во многих, но далеко не во всех случаях исходное выражение Выготского «высшие психологиеские функции» в посмертных изданиях и переизданиях его работ, начиная с «Мышления и речи» (1934), было изменено на «высшие психические функции», а выражение «культурноисторическая теория», согласно Кайлеру, вообще было заимствовано из критического дискурса середины 1930-х и впоследствии приписано Выготскому его критиками, верными учениками, исследователями и последователями (Кайлер, 2012; Кеіler, 2012).

Bmopoe. Недоумение вызывает упоминание рукописи в комментарии Ярошевского в свете известной нам истории о том, что рукопись работы Выготского, по утверждению Лурии, была утрачена. Еще бо́льшие сомнения в правдоподобности ссылки на рукопись Выготского возникают теперь, когда мы знакомы с историей обратного перевода с английского на русский в изложении Эльхонона Гольдберга (Гольдберг, 2012; Goldberg, 2012; Goldberg, 2005, p. 99) и анонимного блогера Ренатуса (А.А. Пузырей) (Ренатус, 2012).

Tpemве. Как известно, 9 октября 1930 г. Выготский выступил с докладом «О психологических системах», который, судя по его тексту и кон- тексту презентации, на его слушателей произвел эффект разорвавшейся бомбы и в конечном счете ознаменовал собой начало перестройки теории и экспериментальной практики на новых основаниях. Идея о межфункциональных связях (лежащая в основе концепции Выготского о функциональных системах) начинает появляться в текстах Выготского уже в 1930 г., например, в третьей части «Педологии подростка» $(1931)^{12}$. Тем не менее понятие функциональной системы, судя по имеющимся в наттем распоряжении текстам, было впервые публично заявлено именно во время программного выступления Выготского 9 октября 1930 г, и в той же «Педологии подростка» (1931) выражения «функциональная система» не найти. С другой стороны, «Орудие и знак» изобилует пространными рассуждениями о «функциональных системах», а само это выражение встречается не менее 15 раз в различных местах текста. Более того, можно вообще сказать, что лейтмотивом всей работы является обсуждение экспериментальных данных, собранных в 1920-е гг., и их анализ сквозь призму новой программы, ориентированной на исследование «функциональных систем». Таким образом, можно утверждать, что эта работа была написана (или существенно отредактирована) не ранее октября 1930 г.

Yетвертое. «Орудие и знак» демонстрирует заметное влияние «полевой» терминологии, представ-

\footnotetext{
${ }^{12}$ См., например, обсуждение датировки других текстов и идей Выготского в их развитии в работе (Яснищкий, 2011б).
} 
ленной не менее чем тремя десятками случаев словоупотреблений понятия «поле» в таких выражениях, как «зрительное поле», «сенсорное поле», «моторное поле», «поле внимания», «поле восприятия», «психическое» или «психологическое поле», «будущее поле действия», «пространственное» и «временно́е поле» и т.п. Наиболее вероятно, что вся эта «полевая» терминология проникла в дискурс Выготского из работ гештальтпсихологов, конкретно именно Курта Левина и его берлинской группы, который как раз в начале 1930-х активно разрабатывал свою топологическую теорию, окончательно сформировавшуюся в ходе топологических семинаров уже после его эмиграции в Америку (см., например: Люк, 2010) и опубликованную в оформленном виде на английском языке в его книге «Принципы топологической психологии» (Lewin, 1936).

Как показывает наше исследование (Ясницкий, 2011a, 2012a, 2012б), контакты между гештальтпсихологами (Куртом Коффкой и Куртом Левином) и коллективом психологов под руководством Льва Выготского и Александра Лурии в 1930-е гг. были особенно тесны и интенсивны.

Пятое. В «Орудии и знаке» имеется фрагмент, в котором его автор (или авторы) рассуждает о том, что «высшие психические функции не надстраиваются, как второй этаж, над элементарными процессами, но представляют собой новые психологические системы» (Выготский, 1984, c. 58). Этот фрагмент является чуть ли ни буквальным повторением идеи, прозвучавшей во время встречи Выготского с его коллегами в конце 1932 г. Конспекты слушателей, участвовавших в этой встрече, были впоследствии опубликованы под именем Выготского и под названием «Проблема сознания» (Выготский, 1932/1968, 1932/1982). Среди личных заметок и записок Выготского сохранилась архивная запись «Symposium 4 декабря 1932 г.», сделанная, очевидно, в ходе подготовки к докладу, в которой среди прочего мы находим такой пассаж:

«Высшие и низшие ф[унк]ции не строятся в 2 этажа: их число и н[а]зв[а]ния не совпадают. Но и не наше прежнее понимание: высшая ф[унк]ция есть овладение низшей (произв. вн[и]м. есть подчинение себе непроизв. вн[и]м[ания]), ибо это и значит - в 2 этажа» (цит. по: Завершнева, 2008, с. 125).

Судя по контексту беседы, эта мысль для Выготского и его сотрудников в декабре 1932 г. была вполне нова и оригинальна и предположительно во время этой встречи прозвучала впервые. Из этого можно заключить, что и последние поправки в текст работы «Орудие и знак» были предположительно внесены не ранее декабря 1932 г.

IIecmoe. И еще один пример. Эволюция представлений Выготского о детской игре также поможет нам более точно датировать текст работы «Орудие и знак». В шестой главе текста (опубликованного под названием «История развития высших психических функций») Выготский развивает свои представления 1920-х гг. о том, что знак, в частности слово, замыкает «непосредственный узел (или связь) между данным словом и соответствующим ему предметом» и что в естественных условиях «эта связь, или условный рефлекс, возникает у 
ребенка естественным путем, поскольку у ребенка нет открытия нового знака, а также и потому, что он употребляет слово как знак этого предмета» (Выготский, 1983, с. 175).

Для экспериментального изучения того, как же возникает этот вызванный словом условный рефлекс, Выпотский и его сотрудники поставили ребенка в искусственную ситуацию игрового замещения названий привычных предметов другими словами естественного языка и выявили, что «ребенок в игре весьма охотно обозначает любой предмет названием любого другого предмета», что «у играющих детей тарелка или часы могут выполнять любую функцию», что в такой игре ребенок производит «ряд простейших действий между этими предметами, и... прекрасно запоминает их символическое значение» (Там же). В следующей седьмой главе ${ }^{13}$ Выготский предлагает теоретическую интерпретацию этих экспериментов. Так, сначала автор постулирует: «в игре для ребенка все может быть всем» - и объясняет это тем, что «сам по себе объект приобретает функцию и значение знака только благодаря жесту, который наделяет его этим значением». Из чего, в свою очередь, следует, что «значение заключается в жесте, а не в объекте», что «относительно безразлично, с каким именно предметом ребенок будет иметь дело в данном случае», поскольку «предмет обязательно должен быть точкой приложения соответствующего символического жеста» (Там же).

Всего несколько лет спустя тема игры опять становится предметом рассмотрения у Выготского, но не как иллюстрация его редукционистских, механистических и рефлексологических схем «инструментального» периода, а с точки зрения вопроса о том, что же составляет собственно психологическое содержание детской игры и какова ее роль в детском развитии. Практически весь набор слов, которыми Выготский описывал игру в конце 1920-х, остается здесь на месте. При этом опять можно найти фразу о том, что «в игре все может быть всем», и упоминание символизма детской игры, однако все интерпретации поменялись на диаметрально противоположные . $^{14}$ Более того, это может показаться поразительным, но, судя по всему, в своих позднейших текстах Выготский вступает в открытую полемику... с самим собой! В самом деле, в своей лекции о детской игре, прочитанной в ЛГПИ им. Герцена в 1933 г. $^{15}$,

${ }^{13}$ Напоминаем: әта глава была впервые опубликована в 1935 г. в составе сборника работ Выготского «Умственное развитие детей в процессе обучения» как выдержка из седьмой главы его неопубликованной рукописи 1928-1929 гг. «История культурного развития нормального и ненормального ребенка». В 1983 г. этот же текст вышел как седьмая глава работы Выготского «История развития высших психических функщий», ошибочно датируемой комментатором этого издания 1931 г. (обсуждение этих и других важнейших публикаций Выготского см.: Ясницкий, 2011б).

${ }^{14}$ Автор признателен Е. Матусову (Dr. Eugene Matusov), подметившему и указавшему ему әто явное противоречие в текстах Выготского.

${ }^{15}$ Стенограмма лекции впервые опубликована в виде статьи в журнале «Вопросы психологии» в 1966 г. 
он недвусмысленно заявляет, что «игра не символика» и что «положение Гете, что для ребенка в игре все может стать всем, - это положение неправильное», так как в детской игре «свойства вещи как таковой сохраняют немалое значение» (Выготский, 1933/1966, с. 70). На примере детской игры с палкой, изображающей лошадь наездника, Выготский иллюстрирует этот тезис, утверждая, что «символ - это знак, а палка - не знак лошади», таким образом, для ребенка в игре «свойства вещи сохраняются, но значение их опрокидывается, т.е. центральным моментом становится мысль» (Там же), а вовсе не жест, как Выготский утверждал всего за несколько лет до этого. Жест, конкретная операция с предметом, безусловно, исключительно важны, но при этом для Выготского периода 1933-1934 гг. внешняя механика второстепенна в психологическом исследовании, уступая по важности механике внутренней: «в игре ребенок оперирует значением, оторванным от вещи, но оно неотрывно от реального действия с реальным предметом» (Там же).

Понятие «смысл» приобретает особое, исключительно важное значение для развития мысли Выготского последние два года его жизни, в 1933-1934 гг. В его лекции об игре 1933 г. «смысл» служит основополагаюшим объяснительным принципом психологического механизма детской игры и ее роли в развитии ребенка в онтогенезе. Выготский говорит о создании «мнимой ситуации» в игре, что становится возможным на основе расхождения «видимого» и «смыслового полей», появляющегося у ребенка в дошкольном возрасте (Там же, с. 65). Такая «мнимая ситуация» неразрывно объединяет самого ребенка, его мысли и действия, мир физических предметов и, что существеннее, мир значений, или же, по выражению Выготского, «смысловое поле». Выготский утверждает, что «ребенок в игре создает такую структуру смысл/вещь, где смысловая сторона, значение слова, значение вещи, является господствующей, определяющей его поведение. Значение эмансипируется до некоторой степени от вещи, с которой оно раньше непосредственно было слито».

Выготский развивает свою мысль и, используя образ дроби, говорит, что, подоб́но тому, как в дроби «вещь/смысл» В детской игре числитель и знаменатель меняются местами, точно такая же трансформация происходит и по отношению операции с вещью и возникает новая дробь «смысл/действие», в которой «структура опрокидывается и определяюшим становится смысл». Таким образом, «действие отодвигается на задний план, становится точкой опоры - опять смысл отрывается от действия с помощью другого действия» (Там же, с. 73), тем самым ребенок, по словам Выготского, совершает «движение в смысловом поле». В свою очередь, «это движение в смысловом поле - самое главное в игре: оно, с одной стороны, есть движение в абстрактном поле (поле, значит, возникает раньше, чем произвольное оперирование значениями), но способ движения - ситуационный, конкретный (т.е. не логический, а аффективное движение)» (Там же). Теоретическое значение 
этой внутренней полемики в работах Выготского разных периодов будет затронуто в отдельном специальном исследовании. Сейчас же рассмотрим представления о детской игре автора текста «Орудие и знак в развитии ребенка» и проанализируем, как они соотносятся с двумя полярными взглядами на эту тему, выраженными в других работах Выготского.

\section{Заочный диалог переводчиков: обсуждение детской игры в трех версиях одного текста}

Взгляды на детскую игру в тексте «Орудие и знак» представлены в одном дублирующемся фрагменте текста, который в некоторой степени проливает свет на «творческий метод» переводчиков, предположительно работавших над его переводом с английского, и, с другой стороны, проясняет историю развития представлений об игре среди исследователей круга Выготского. Интересующий нас фрагмент представлен в таблице 4, где в первой колонке мы видим первый фрагмент, а в последней колонке второй фрагмент, условно названные здесь соответственно «Перевод $A$ и «Перевод Б» (ср. соответственно Фрагмент 1 и Фрагмент 1', представленные в таблице 3). В средней колонке приведен текст английской версии рукописи, послуживший предположительно основой для этих двух переводов. В первую очередь нас здесь интересуют те случаи, когда русские версии текста расходятся между собой, но имеют прямые аналоги в английском тексте. Буквальные текстуальные соответствия обозначены в тексте жирным шрифтом, незначительные отклонения от английского оригинала выделяются курсивом, а грубые ошибки, возникшие в результате таких отклонений и приведшие к внутренним противоречиям в русском тексте «Орудие и знак» советского издания 1984 г., обозначены одновременно курсивом и подчеркиванием. Для удобства обсуждения результатов анализа фрагменты текста в таблице разбиты по предложениям и пронумерованы (нумерация предложений представлена только в первой колонке).

Начнем с общей сравнительной характеристики этих двух переводов. В целом, насколько вообще можно судить по приведенному фрагменту, следует сказать, что «переводчик Б» сделал перевод более буквальный и близкий к тексту оригинала. Тем не менее в двух случаях «переводчик А» был ближе к оригиналу (см. предложения 3 и 4); в одном из данных случаев это оказалось весьма существенно, а именно в предложении 3 была сохранена цитата оригинала: «не “все может быть всем" в игре ребенка» (Выготский, 1984, с. 15). «Переводчик Б» использовал при этом существенно отличную по смыслу фразу - «не все вещи одинаково важны», подразумевающую мысль о ранжировании физических объектов по важности в детской игре, чего не найти в двух других версиях этого текста.

В двух других случаях «переводчик Б» допустил две грубые ошибки (см. предложения 6 и 7), что привело к появлению взаимоисключающих утверждений на разных страницах одного и того же русского текста «Орудие и знак»; так, версии о том, что «стол будет гореть» (на с. 15), 
Три фрагмента текста «Орудие и знак» с рассуждением об игре

\begin{tabular}{|c|c|c|}
\hline $\begin{array}{c}\text { Орудие и знак в развитии } \\
\text { ребенка, Собрание сочинений, } \\
\text { т. } 6,1984, \text { с. } 14-15 \text { «Перевод А» }\end{array}$ & $\begin{array}{c}\text { Tool and symbol in child deve- } \\
\text { lopment, Vygotsky reader, 1994, } \\
\text { p. } 151-152\end{array}$ & $\begin{array}{c}\text { Орудие и знак в развитии } \\
\text { ребенка, Собрание сочинений, } \\
\text { т. } 6,1984, \text { с. } 69-70 \text { «Перевод Б» }\end{array}$ \\
\hline $\begin{array}{l}\text { 1. Опыты показывают, что } \\
\text { ребенку в игре и в речи чуждо } \\
\text { сознание условности, про- } \\
\text { извольности соединения знака } \\
\text { и значе-[с. 15]ния. }\end{array}$ & $\begin{array}{l}\text { Experiments show that both in } \\
\text { play and in speech the child is far } \\
\text { from consciously realizing the } \\
\text { relativity of the sign operation or } \\
\text { of the arbitrarily established con- } \\
\text { nection of sign and meaning. }\end{array}$ & $\begin{array}{l}\text { Эксперименты показывают, что } \\
\text { в игре и речи ребенок далек от } \\
\text { сознания условности знаковой } \\
\text { операции, от сознания про- } \\
\text { извольно устанавливаемой связи } \\
\text { между знаком и значением. }\end{array}$ \\
\hline $\begin{array}{l}\text { 2. Для того чтобы быть знаком } \\
\text { вещи, слово должно иметь } \\
\text { опору в свойствах обозначаемо- } \\
\text { го об́ъекта. }\end{array}$ & $\begin{array}{l}\text { In order to become an object's } \\
\text { (word's) sign, the stimulus finds } \\
\text { support in the properties of the } \\
\text { designated object itself. }\end{array}$ & $\begin{array}{l}\text { Чтобы стать знаком вещи } \\
\text { (слова), стимул должен иметь } \\
\text { опору в качествах самого обо- } \\
\text { значаемого объекта. }\end{array}$ \\
\hline $\begin{array}{l}\text { 3. Не «все может быть всем» в } \\
\text { игре ребенка. }\end{array}$ & $\begin{array}{l}\text { Not 'everything can rep1 } \\
\text { everything' for the child } \\
\text { game. }\end{array}$ & $\begin{array}{l}\text { Не все веши одинаково важны } \\
\text { для ребенка в такой игре. }\end{array}$ \\
\hline $\begin{array}{l}\text { 4. Реальные свойства вещи и ее } \\
\text { символическое знаиение обнару- } \\
\text { живают в игре сложное струк- } \\
\text { турное взаимодействие. }\end{array}$ & $\begin{array}{l}\text { The objects' real properties and } \\
\text { their sign meanings come into } \\
\text { complex structural interaction } \\
\text { during play. }\end{array}$ & $\begin{array}{l}\text { Реальные качества вещи и их } \\
\text { знаковое значение вступают в } \\
\text { игре в сложные структурные } \\
\text { взаимоотноие-[с. } 70] \text { ния. }\end{array}$ \\
\hline $\begin{array}{l}\text { 5. Так же и слово связывается } \\
\text { для ребенка с вещью через ее } \\
\text { свойства, вплетаясь в их общую } \\
\text { структуру. }\end{array}$ & $\begin{array}{l}\text { Thus, for the child, the word is lin- } \\
\text { ked to the object through the lat- } \\
\text { ter's properties and is incorporated } \\
\text { in one structure, common to it. }\end{array}$ & $\begin{array}{l}\text { Таким образом, слово для } \\
\text { ребенка связано с вещью через } \\
\text { ее качества и включено в } \\
\text { об́щую с ним структуру. }\end{array}$ \\
\hline $\begin{array}{l}\text { 6. Поэтому ребенок в наших } \\
\text { опытах не соглашается с тем, } \\
\text { что можно было бы пол назы- } \\
\text { вать стаканом («по нему. } \\
\text { ходить нельзя будет»), но дела- } \\
\text { ет стул поездом. изменяя в игре } \\
\text { его свойства, т.е. обращаясь с } \\
\text { ним как с поездом. }\end{array}$ & $\begin{array}{l}\text { That is why the child in our expe- } \\
\text { riments refuses to call the floor a } \\
\text { mirror (it cannot walk on a mir- } \\
\text { ror), but has no qualms at [152] } \\
\text { transforming a chair into a train, } \\
\text { using its properties in play, i.e. } \\
\text { manipulating it as if it were a } \\
\text { train. }\end{array}$ & $\begin{array}{l}\text { Поэтому ребенок в наших экс- } \\
\text { периментах не соглашается } \\
\text { назвать пол зеркалом (он не } \\
\text { может пройти по зеркалу), но } \\
\text { превращает стул в поезд, при- } \\
\text { меняя в игре его качества, т. е. } \\
\text { манипулируя с ним как с } \\
\text { поездом. }\end{array}$ \\
\hline $\begin{array}{l}\text { 7. Ребенок отказывается пере- } \\
\text { менить знаиения слов «стол» и } \\
\text { «лампа», потому что «на лампе } \\
\text { нельзя будет писать, а стол } \\
\text { бидет гореть». }\end{array}$ & $\begin{array}{l}\text { When asked to call a lamp 'table' } \\
\text { and vice versa, the child refuses, } \\
\text { because one 'can't write on a } \\
\text { lamp, or tum on a table'. }\end{array}$ & $\begin{array}{l}\text { Ребенок отказывается называть } \\
\text { лампу столом и наоборот, так } \\
\text { как «нельзя писать на лампе, а } \\
\text { стол не может гореть». }\end{array}$ \\
\hline $\begin{array}{l}\text { 8. Изменить название - значит } \\
\text { для него изменить свойства } \\
\text { вещи. }\end{array}$ & $\begin{array}{l}\text { To change (or swap) meanings for } \\
\text { the child means to change the } \\
\text { properties of objects. }\end{array}$ & $\begin{array}{l}\text { Заменить обозначения для } \\
\text { него - значит заменить каче- } \\
\text { ства вещей. }\end{array}$ \\
\hline
\end{tabular}


противостоит указание на то, что «стол не может гореть» (на с. 70 ), а интерпретации, согласно которой ребенок изменяет в игре свойства предмета, в другом месте (на с. 15) противоречит положение, что в игре ребенок применяет (иными словами, использует) качества предмета. Данное положение можно найти также на с. 70.

Курьезное расхождение в двух версиях предложения 6 , где в «переводе $\mathrm{A} »$ фигурирует «стакан», а в «переводе Б» речь идет о «веркале», может свидетельствовать о том, что оба переводчика пользовались предположительно вариантом английского текста, несколько отличным от того, что был опубликован в издании 1994 г.: в этом гипотетическом тексте вместо английского слова «mirror» было предположительно использовано слово «glass», обозначающее, как известно, одновременно и «стакан» и «зеркало». Также дает нам основания для вывода о предположительном существовании несколько отличной от опубликованной версии английского текста то обстоятельство, что оба русских текста упоминают о способности лампы «гореть» в нормальной, неигровой ситуации, подразумевая, очевидно, не электрическую, а, скажем, масляную лампу. Английский текст 1994 г., с другой стороны, предлагает несколько модернизированный образ электрической лампы, которую в неигровых условиях можно «включить» (turn on). Эти расхождения между предположительно англоязычным источником и русскими переводами опять же можно объяснить позднейшей правкой английской рукописи текста. Так или иначе в большинстве случаев второй вариант ближе к известному нам английскому тексту в том смысле, что «переводчик Б» явно стремился дословно передать текст оригинала (точнее сказать, первого перевода c русского на английский $\left.{ }^{16}\right)$, а потому может считаться более достоверным настолько, насколько двойной перевод в принципе можно рассматривать с точки зрения достоверности.

Что же касается содержания, то, насколько нам позволяет судить о том обратный перевод на русский, этот текст занимает промежуточное и, вероятно, переходное положение между работами конца 1920-х и лекцией об игре 1933 г. Автор текста уже отказывается от идеи произвольно устанавливаемой искусственной связи между словом и предметом в игре; нет здесь и положения о ведущей роли жеста в формировании значения, и механистических спекуляций о замыкании условно-рефлек-

\footnotetext{
${ }^{16}$ Как мы знаем из других довоенных публикаций Выготского, Лурии и других представителей круга Выготского, подавляющее большинство их публикаций на английском языке - если не все - были переведены с русского оригинала. Среди известных нам переводчиков работ Лурии и Выготского на английский следует назвать таких брокеров между советской и международной, североамериканской наукой, как Хорсли Гантт (W. Horsley Gantt), Джейкоб Казанин (Jacob Kasanin), Евгения Ханфманн (Eugenia Hanfmann) и Хелен Коган (Helen Kogan). (Об иностранных и иноязычных публикациях психологов довоенной поры см.: Ясницкий, 2011в, о международных научных брокерах см.: Ясницкий, 2011а, 2012a, 2012б.)
} 
торных связей между предметом и новым, игровым его обозначением, напротив, какие-то формулировки дословно повторяют или же (что более вероятно) предвосхищают положения ленинградской лекции об игре 1933 г., например, фраза о том, что «не “все может быть всем” в игре ребенка» (Выготский, 1984, с. 15). C другой стороны, здесь еще нет ни «мнимой ситуации», ни рассуждений о смыслообразовании и тому подобных тем, характерных для дискурса Выготского периода 1933 1934 гг. Думается, что (судя по степени развитости представлений автора об игре в әтом фрагменте) мы имеем основания датировать этот конкретный отрывок текста приблизительно 1932 г.

Вернемся же к вопросу о датировке всего текста «Орудие и знак в развитии ребенка». На основании приведенных данных приходится существенно уточнить датировку работы «Орудие и знак в развитии ребенка», которая традиционно считается совпадающей по времени создания с такими опусами, как рукописи работ по «истории развития функций» или третья книга трехтомника «Педология подростка» (см. выше). По всей видимости, следует переопределить «Орудие и знак» как текст, последние изменения в который были внесены ориентировочно в 1932 - начале 1933 г., хотя при этом остаются и определенные неясности, вызванные использованием автором несколько анахроничной для этого периода терминологии. Так, например, понятие «стимул» и его производные появляются в этом тексте свыше 60 раз, что более характерно для ранних текстов Выготского и совершенно нетипично для его более поздних текстов. Впрочем, мы можем предположить, что высокая частотность слова «стимул» является артефактом двойного перевода этого текста сначала с русского языка на английский, а затем обратно с английского на русский язык.

\section{«Благая весть» от Иванова: четвертая версия текста, апокрифическая}

Прежде чем мы завершим анализ дошедших до нас версий рассматриваемого здесь текста, мы должны особо рассмотреть еще один эпизод всей этой непростой истории. Как мы уже упоминали в начале нашего обсуждения, текст Выготского (и Лурии) про орудие и знак был известен советским ученым и до его первой публикации на русском языке в 1984 г. Об этом мы знаем от советского и русского ученого - лингвиста и семиотика - Вячеслава Всеволодовича Ива́нова (1929-2017), который занимает воистину особое и далеко не случайное место в истории публикации и распространении текстов и идей Выготского (и Лурии) в стране и за ее пределами.

Следует помнить, что Иванов вопреки тенденциям и настроениям своего времени преодолел фактический «запрет на Выготского», существовавший в СССР в 1960-1970-е гг., при котором Выготский был номинально провозглашен «отцом-основателем» и «любимым учителем» ряда ведущих советских психологов того времени, но работы его после публикации двух томов в 1956 и 1960 гг. не переиздавались, а идеи постепенно забывались и выходили из обихода. 
Обсуждение этого «фактического запрета на Выготского» в СССР периода 1960-1970-х велось как в классических текстах (Зинченко, 2003; Щедровицкий, 2001) ${ }^{17}$, так и в недавних публикациях (Fraser, Yasnitsky, 2016; Yasnitsky, Van der Veer, 2016).

И в самом деле, в ходе работы в архивах известного советского кинорежиссера и теоретика искусства и кинематографа С.M. Эйзенштейна (1898-1948) Иванов обнаружил рукопись работы Выготского «Психология искусства», а затем инициировал ее публликацию в советском издательстве «Искусство» в 1965 г. Второе, расширенное издание книги включало еще одну неопубликованную рукопись Выготского (его студенческую работу о «Гамлете» Шекспира), обнаруженную публикатором в архивах семьи Выготского, и вышло в 1968 г. (Выготский, 1965, 1968). При этом Иванов обнаружил себя большим знатоком не только архивов, но и теоретического наследия Выготского (и Эйзенштейна), свидетельством чему являются многостраничные комментарии к изданию текста. Таким образом, мы понимаем, что Иванов был (и остается) одним из пионеров выготсковедения, открывшим «неизвестного Выготского» широкой читательской публике в СССР в 1960-1970-е гг. Уже по одной этой причине его словам следует придавать особое значение, а утверждения о тех или иных текстах Выготского принимать со всей серьезностью.

Выготский играет одну из важнейших ролей в построении и аргументации книги Иванова. Так, говоря о исторических предшественниках семиотики, Иванов подчеркивает, что «из других советских ученых, уже во второй четверти [двадцатого] века много сделавших для науки о знаковых системах, особенно выделяются труды психолога Л.С. Выготского, который знаки рассматривал как средства управления поведением человека» (Иванов, 1976, с. 3) В контексте нашего обсуждения обращает на себя внимание специальное указание автора, что работа над книгой была начата еще в 1952 г., что «книга в большой степени построена на исследовании еще не опубликованных архивных документов» и что «автор пользуется случаем принести благодарность семье Л.С. Выготского», «способствовавшей его занятиям» (Там же, с. 4).

В этом свете особенный интерес привлекает одна цитата, которую можно найти на страницах «Очерков по истории семиотики в СССР» (Иванов, 1976) ${ }^{18}$. Итак, в этой книге, в контексте обсуждения «вероятных

${ }^{17}$ Тексты доступны в Интернете, см., соответственно: http://www.anleontiev.smysl.ru/vospomin/i-zinch.htm и http://samlib.ru/s/shedrowickij_g_p/gp_i1-2.shtml (развернутая версия: http://lizard.jinr.ru/ tina/world/history/schedr/GP001.html) или, например: http:// www.ansya.ru/health/istoriya-psihologov-i-istoriya-psihologii-to-vdrug-neojidanno/main.html

${ }^{18}$ Следует напомнить читателю, что полный текст книги доступен в Интернете, например, на сайте Института славяноведения РАН; см. источник по адресу: http://www.inslav.ru/ resursy/elektronnaya-biblioteka/2071-1976-ivanov; см. также: http://philologos.narod.ru/semiotics/ivanov_semio.htm 
отличий предполагаемых ранних форм жестовой коммуникации от поведения антропоидов» автор упоминает и мысль, по его утверждению, «высказанную Выготским в 1931 г. в его работе “Орудие и знак в развитии ребенка"» (Там же, с. 29). За этим следует цитата из неопубликованной работы, источник которой указан автором как «архив Л.С. Выготского» и соответствие которой мы постарались найти в известных нам текстах Выготского публикаций 1984 (на русском) и 1994 гг. (на английском языке). Буквальное соответствие в разных вариантах текста на двух языках не было обнаружено. Тем не менее были найдены два фрагмента, которые максимально, в той или иной степени близки мысли, выраженной в цитате Иванова в его книге 1976 г. Все эти фрагменты представлены ниже в табличном виде, при этом для удобства понимания и анализа текста цитата разбита прерывистой линией на две смысловые фразы (см. таблицу 5).

Итак, о чем свидетельствует анализ представленных здесь фрагментов текста?

Во-первых, хорошо видно, что Фрагмент 1 и Фрагмент 2 текста (на

Таблииа 5

Цитата фрагмента текста «Орудие и знак» из книги Иванова «Очерки по истории семиотики в СССР» и предположительно соответствующие ей места из изданий 1984 и 1994 гт.

\begin{tabular}{|c|c|c|c|c|}
\hline \multirow{2}{*}{$\begin{array}{l}\text { Иванов, Очерки по } \\
\text { истории семиотики } \\
\text { в СССР, 1976, с. } 29\end{array}$} & \multicolumn{2}{|c|}{$\begin{array}{c}\text { Орудие и знак в развитии ребенка, } \\
\text { собрание сочинений, т. } 6,1984\end{array}$} & \multicolumn{2}{|c|}{$\begin{array}{l}\text { Tool and symbol in child develop- } \\
\text { ment, Vygotsky reader, } 1994\end{array}$} \\
\hline & $\begin{array}{c}\text { Фрагмент } 1 \text { (рус.), } \\
\text { с. } 10\end{array}$ & $\begin{array}{l}\text { Фрагмент } 2 \\
\text { (рус.), с. } 24\end{array}$ & $\begin{array}{l}\text { Фрагмент } 1 \\
\text { (англ.), р. } 103\end{array}$ & $\begin{array}{l}\text { Фрагмент } 2 \\
\text { (англ.), p. } 111\end{array}$ \\
\hline $\begin{array}{l}\text { Если поведение } \\
\text { обезьяны в } \\
\text { экспериментальной } \\
\text { ситуации } \\
\text { (требующей } \\
\text { применения } \\
\text { орудий), согласно } \\
\text { Келеру, } \\
\text { обусловлено } \\
\text { главным образом } \\
\text { зрительным полем, }\end{array}$ & $\begin{array}{l}\text { Если поведение } \\
\text { обезьяны в } \\
\text { экспериментальной } \\
\text { ситуации, требующей } \\
\text { употребления орудий, } \\
\text { определяется, как } \\
\text { показал Келер, } \\
\text { главным образом } \\
\text { структурой } \\
\text { зрительного поля, }\end{array}$ & $\begin{array}{l}\text { Поведение } \\
\text { обезьяны, } \\
\text { описанное } \\
\text { Келером, } \\
\text { ограничено } \\
\text { манипулирова- } \\
\text { нием животного в } \\
\text { непосредственно } \\
\text { данном } \\
\text { зрительном поле, }\end{array}$ & $\begin{array}{l}\text { If ape behavior is } \\
\text { an experimental } \\
\text { situation which } \\
\text { requires the use of } \\
\text { tools is, according } \\
\text { to Köhler, deter- } \\
\text { mined chiefly by } \\
\text { the structure of } \\
\text { its optic field, }\end{array}$ & $\begin{array}{l}\text { The behaviour } \\
\text { of an ape, } \\
\text { described by } \\
\text { Kohler, is limit- } \\
\text { ed to the ani- } \\
\text { mal's manipula- } \\
\text { tion in a given } \\
\text { field of vision, }\end{array}$ \\
\hline $\begin{array}{l}\text { то ребенок } \\
\text { действует прежде } \\
\text { всего при помощи } \\
\text { своей «naive } \\
\text { Physik» (наивной } \\
\text { физики), т.е. своего } \\
\text { примитивного } \\
\text { опыта о физической } \\
\text { природе среды и } \\
\text { своего тела. }\end{array}$ & $\begin{array}{l}\text { то у ребенка на } \\
\text { первый план в } \\
\text { качестве } \\
\text { определяющего } \\
\text { фактора выступает } \\
\text { «наивная физика», } \\
\text { т.е. его наивный опыт, } \\
\text { касающийся } \\
\text { физических свойств } \\
\text { окружающих его } \\
\text { объектов и } \\
\text { собственного тела. }\end{array}$ & $\begin{array}{l}\text { тогда как } \\
\text { решение } \\
\text { практической } \\
\text { проблемы } \\
\text { ребенком, } \\
\text { способным } \\
\text { говорить, в } \\
\text { значительной } \\
\text { степени } \\
\text { отдаляется от } \\
\text { натурального } \\
\text { поля. }\end{array}$ & $\begin{array}{l}\text { the determining } \\
\text { factor in the child } \\
\text { is 'naive Physik' } \\
\text { (naive physics) } \\
\text { i.e. primitive } \\
\text { experience con- } \\
\text { cerning the physi- } \\
\text { cal nature of its } \\
\text { environment and } \\
\text { of its body. }\end{array}$ & $\begin{array}{l}\text { whereas the } \\
\text { solution of a } \\
\text { practical prob- } \\
\text { lem by a speak- } \\
\text { ing child } \\
\text { becomes, to a } \\
\text { great extent, } \\
\text { removed from } \\
\text { this natural } \\
\text { field. }\end{array}$ \\
\hline
\end{tabular}


русском и английском языках) обнаруживают как определенные черты сходства (по большей части в первой половине предложения), так и несомненные различия (во второй фразе предложения). Рассуждая о причинах сходства этих, фрагментов вряд ли стоит говорить о небуквальных смыслоовых пlовторах, как мы это делали в контексте обсуждения работы двух (или более) переводчиков текста. По всей видимости, здесь мы имеем дело с авторским повтором, какие иной раз нередко непроизвольно случаются в процессе создания научного текста.

Во-вторых, сравнение русских фрагментов с их английскими соответствиями обнаруживает дополнительные различия, которые ставят новые вопросы о терминологической последовательности в использовании тех или иных слов и выражений (как, например, степень смысловой эквивалентности выражений «зрительное поле», «натуральное поле», «физические свойства окружающих объектов и собственного тела», «optic field», «field of vision», «natural field» и «physical nature of its environment and of [one's] body»). Далее, эти вопросы при условии их системной проработки на материале разных вариаций данного текста подталкивают нас к осмыслению степени теоретической зрелости и концептуальной целостности и последовательности научных идей, представленных в этой работе. Тем не менее анализ такой глубины решительно выходит за рамки нашего обсуждения и остается задачей будущего.

И наконец, в-третьих, очевидно, что книга Иванова приводит фрагмент текста, не имеющий аналогов в двух фрагментах на русском языке, причем русский Фрагмент 1 (вторая колонка таблицы) по своей сути и смыслу явно ближе к цитате Иванова, чем русский Фрагмент 2 (третья колонка). Более того, английский Фрагмент 1 (четвертая колонка) по смыслу и фразеологии, пожалуй, еще ближе формулировке цитаты 1976 г., что позволяет допустить происхождение этой цитаты как еще один перевод $\mathrm{c}$ английского языка, вероятно, сделанный автором избирательно и специально в целях цитирования текста. В то же время ряд мелких различий в двух версиях этой фразы, такие как пропуск упоминания «структуры» поля или, скажем, «детерминирующего фактора» в русском тексте (ср. первую и четвертую колонки таблицы), позволяет также допустить, что опубликованная Ивановым цитата из его книги 1976 г. на самом-то деле не была переведена с английского текста и что автор книги цитировал дословно имевшийся у него на руках русский текст.

Если это допущение окажется верным, то придется признать, что, помимо известных нам английского текста работы и не менее двух версий его обратного перевода на русский язык в середине 1970-х гг., где-то (предположительно, как указал Иванов в своей книге, «в архиве Л.С. Выготского») существовал и еще один вариант рукописи этой работы. Можно предположить, что этот вариант рукописи и был ее оригинальной версией, созданной еще при жизни Выготского, в начале 1930-х гг. Дальнейшая судьба и местонахождение этой гипотетической рукописи остаются для нас загадкой и по сей день. Ввиду полной таинственности 
и непризнанности в качестве канонической будем считать - и называть эту гипотетическую версию текста «апокрифической».

\section{Подводим итоги: датировка текста и проблема аутентичности в современном ревизионистском выготсковедении}

Итоги рассмотрения работы «Орудие и знак в развитии ребенка» могут быть представлены в виде ряда основных выводов.

1. У нас есть все основания полагать, что какой-то текст был действительно создан в соавторстве Выготским и Лурией не позднее конца 1930 г. Более того, можно предположить, что этот текст был в целом очень близок по содержанию и даже по формулировкам другим итоговым текстам того времени. Например, особое внимание в этом отношении привлекает несколько необычная работа - единственный известный нам текст на французском языке, прижизненно опубликованный под именем Выготского под названием «Le problème des fonctions intellectuelles supérieures dans le système des recherches psychotechniques» в материалах VI международного психотехнического съезда в Испании (Барселона, 23-27 апреля 1930 г.), и его русский аналог, вышедший под названием «Проблема высших интеллектуальных функций в системе психотехнического исследова- ния» в журнале «Психотехника и психофизиология труда» ${ }^{19}$. Обе публикации состоялись в 1930 г. (Vigotski, 1930; Выготский, 1930) ${ }^{20}$.

2. Тем не менее работа «Орудие и знак в развитии ребенка» русского издания 1984 г. и английского издания 1994 г. ни при каких обстоятельствах не могла быть рукописью, предположительно отправленной в 1930 г. для публикации в «Handbook of child psychology» (1931). Этот текст был порожден в процессе обратного перевода с английского языка двумя (или более) переводчиками, в результате чего некоторые сегменты текста были продублированы и включены в виде небуквальных повторов в русской публикации 1984 года и последовавшими на ее основании переводов на английский, испанский и другие языки. (Обсуждение и анализ таких дальнейших «переводов второго порядка» и дальнейших искажений текста, вызванных многократным переводом, см.: Yasnitsky, Van der Veer, 2016.) Не следует исключать и существование «апокрифического» текста, до сих пор не известного широкой публике, но который в определенный момент в середине 1970-х гг. был доступен В.В. Иванову при подготовке его классической работы «Очерки по истории семиотики в СССР» (Иванов, 1976).

3. Датировать последние редакции (предположительно состоявшиеся еще при жизни Выготского) известного нам текста этого произве-

${ }^{19}$ См. также публикацию текста в Интернете: http://psyjournals.ru/kip/2007/n3/Vygotsky_full.shtml.

${ }^{20}$ Самую полную академическую библиографию прижизненных публикаций Выготского на шести языках и аналитические материалы к ней см.: Yasnitsky, Van der Veer, 2016. 
дения следует, пожалуй, не ранее конца 1932 г., а возможно, даже и 1933 г. Только специальное исследование сможет помочь нам определить источник анахронизмов и следов сравнительно более ранних идей, установить объем редакторских манипуляций с текстом рукописи и разъяснить историю этого текста в период между 1930 г, когда какая-то его версия предположительно была отправлена издателям в США для публикации на английском языке, и началом 1970-х, когда какая-то рукопись (точнее: машинопись) на английском языке была передана Лурией Коулу для публикации на Западе. Различия между этими двумя текстами периодов 1930-х и 1970-х и степень редакторского вмешательства Лурии и/или третьих лиц остаются полной загадкой для нас по сей день.

4. Между тем уже сейчас можно утверждать, что доверие к русскоязычному тексту, опубликованному издательством «Педагогика» в 1984 г. в шестом томе собрания сочинений Выготского, как к аутентичному тексту Выготского (и Лурии) начала 1930-х гг. окончательно, безнадежно и бесповоротно подорвано. Впрочем, справедливости ради следует заметить, что существуют определенные сомнения в аутентичности целого ряда известных нам текстов этого автора, вышедших в советских изданиях преимущественно послевоенного периода. Скрупулезная работа по восстановлению и реконструкции аутентичных слов, фраз, текстов и смыслов как раз и составляет «критическое», или же «текстологическое», направление в ревизионистском течении современного международного выготсковедения, стремительное распространение которого во всем мире мы наблюдаем в наши дни (Yasnitsky, 2012; Yasnitsky, Van der Veer, 2016; Yasnitsky et al., 2016; Zavershneva, Van der Veer, 2018; Завершнева, Ван дер Веер, 2017).

\section{Литература}

Ван дер Веер, Р. (2012). Рукописи не горят, не так ли? Психологический журиал Международного университета природы, общества и человека «Дубна», 1, 139-144.

Выподская, Г. Л., Лифанова, Т. М. (1996). Лев Семенович Выготский. Жизнь. Деятельность. Штрихи к портрету. М.: Смысл.

Выготский, Л. С. (1930). Проблема высших интеллектуальных функций в системе психотехнического исследования. Психотехника и психофизиология труда, 3(5), 374-384.

Выготский, Л. С. (1932/1968). Проблема сознания (1932). В кн. А. А. Леонтьев, Т. В. Рябова (ред.), Психология грамматики (с. 178-196). М.: Изд-во Московского Университета.

Выготский, Л. С. (1932/1982). Проблема сознания (1932). В кн. Л. С. Выготский, Собрание сочинений (т. 1, с. 156-166). М.: Педагогика.

Выготский, Л. С. (1933/1966). Игра и ее роль в психическом развитии ребенка (1933). Boпросы психологии, 6, 62-76.

Выготский, Л. С. (1934). Мыиление и реиь. Психологические исследования. М.: Соцэкгиз.

Выготский, Л. С. (1965). Психология искусства. М.: Искусство.

Вьготский, Л. С. (1968). Психология искусства (2-е изд.). М.: Искусство. 
Выготский, Л. С. (1983). История развития высших психических функций. В кн. Л. С. Выготский, Собрание сочинений (т. 3, с. 5-328). М.: Педагогика.

Выготский, Л. С. (1984). Орудие и знак в развитии ребенка. В кн. Л. С. Выготский, Собрание сочинений (т. 6, с. 5-90). М.: Педагогика.

Гольдберг, Э. (2012). «Спасибо за эти замечательные материалы - очень интересно». Психологический журнал Международного университета природы, общества и человека «Дубна», 1, 121-123.

Завершнева, Е. Ю. (2008). Записные книжки, заметки, научные дневники Л.С. Выготского: результаты исследования семейного архива (часть 2). Вопросы психологии, 2, 120-136.

Завершнева, Е., ван дер Веер, Р. (Ред.). (2017). Записные книжки Л.С. Выготского. Избранное. М.: Канон + РООИ «Реабилитация».

Зинченко, В. П. (2003). «Да, очень противоречивая фигура...». Журнал практического психолога, $1-2,162-179$.

Иванов, В. В. (1976). Очерки по истории семиотики в СССР. М.: Наука.

Кайлер, П. (2012). «Культурно-историческая теория» и «культурно-историческая школа»: От мифа (обратно) к реальности. Психологический журнал Международного университета природы, общества и иеловека «Дубиа», 1, 34-46.

Коул, М. (2012). Комментарии к предыдущим комментариям. Психологииеский журнал Международного университета природь, общества и иеловека «Дубна», 1, 128-132.

Люк, Х. (2010). Групповые процессы в научных исследованиях (на примере «Топологической группы» Курта Левина). Методология и история психологии, 5(3), 77-89.

Ренатус (Пузырей, А. А.). (2012). «Дело в том, что в архиве Выготского нашли поначалу только английскую версию этого текста...». Психологииеский журнал Международного университета природы, общества и человека «Дубна», 1, 114-117.

Шедровицкий, Г. П. (2001). Я всегда был идеалистом... М.: Путь.

Ярошевский, М. Г. (1984). Комментарии. В кн. Л. С. Выготский, Собрание сочинений (т. 6, с. $348-$ 356). М.: Педагогика.

Ясницкий, А. (2011а). Изоляционизм советской психологии? Ученые, «импорт-экспорт» в науке и власть. Вопросы психологии, 6, 108-121.

Ясницкий, А. (2011б). «Когда б вы знали, из какого сора...»: К определению состава и хронологии создания основных работ Выготского. Психологиеский журнал Международного университета природы, общества и иеловека «Дубиа», 4, 1-52.

Ясницкий, А. (2011в). Об изоляционизме советской психологии: научные публикации 1920-30-х годов. Вопросы психологии, 1, 124-136.

Ясницкий, А. (2012а). Изоляционизм советской психологии? Неформальные личные связи ученых, международные посредники и «импорт» психологии. Вопросы психологии, 1, 100-112.

Ясницкий, А. (2012б). К истории культурно-исторической гештальтпсихологии: Выготский, Лурия, Коффка, Левин и др. Психологический журнал Международного университета природы, общества и человека «Дубна», 1, 60-97.

Ссылки на зарубежные источники см. в разделе References после англоязынного блока.

Ясницкий Антон - независимый исследователь, Ph.D.

Сфера научных интересов: круг Выготского-Лурии, культурно-историческая гештальтпсихология, дизайн и менеджмент научных революций, дисциплинарная и транснациональная история науки.

Контакты: anton.yasnitsky@gmail.com 


\title{
A. Yasnitsky. "Tool and Sign": The Most Famous Vygotsky's Work that He Never Wrote
}

\author{
Anton Yasnitsky
}

${ }^{a}$ Independent researcher

\begin{abstract}
Tphe article discusses the history of the creation, multiple translation, falsification and eventual publication of a text by Vygotsky and Luria. Following this publication, the text was declared one of the foundational works of Vygotsky. The study traces the way from the original version of the text (reportedly originally composed in the late 1920s) to the typed version of the text in English that Luria passed to Michael Cole for subsequent publication in the West and, finally, to the Russian version of the text that was back-translated from English when the original Russian text was lost. The study is based on the comparative structural and textological analysis of the text and its repeating fragments (i.e., the non-verbatim semantic repetitions of the text both in the Russian version and, comparatively, in the multilingual versions of the text in English and Russian). Also, the study involved the analysis of the archival documents and memoir publications. The paper demonstrates that the Russian text of the work "Tool and sign in the development of the child" that was first published in Russian in 1984 under the editorship of M.G. Yaroshevsky was created as a result of manipulations caused by the uncoordinated work of two (or more) translators and, not unlikely, further editorial interventions. The study comes to the conclusion that the Russian text of the 1984 Pedagogika Press edition of the six-volume Collected works by Vygotsky is definitely and hopelessly discredited as Vygotsky's (and Luria's) authentic text of the late 1920s-early 1930s. Finally, the paper discusses the problem of the possible periodization of this text and, further, the problem of authenticity from the standpoint of contemporary revisionist Vygotsky Studies.
\end{abstract}

Keywords: Vygotsky, Yaroshevskii, censorship, falsification, textology, comparative analysis, archive, memoirs, "Tool and sign".

\section{References}

Cole, M. (2004). Prologue: Reading Vygotsky. In R. W. Rieber \& D. K. Robinson (Eds.), The essential Vygotsky (pp. vii-xii). New York: Kluwer Academic/Plenum Publishers.

Cole, M. (2012). Comments on prior comments. PsyAnima, Dubna Psychological Journal, 5(1), 124-127.

Cole, M., John-Steiner, V., Scribner, S., \& Souberman, E. (1978). Editors' preface. In L. S. Vygotsky, Mind in society: the development of higher psychological processes (pp. ix-xi). Cambridge: Harvard University Press.

Fraser, J., \& Yasnitsky, A. (2016). Deconstructing Vygotsky's victimization narrative: A re-examination of the «Stalinist suppression» of Vygotskian theory. History of the Human Sciences, 28(2), 128-153.

Garai, L., \& Kocski, M. (1995). Another crisis in the psychology: A possible motive for the Vygotskyboom. Journal of Russian and East-European Psychology, 33(1), 82-94. 
Goldberg, E. (2001). The executive brain: Frontal lobes and the civilized mind. New York: Oxford University Press.

Goldberg, E. (2005). The wisdom paradox: How your mind can grow stronger as your brain grows older. New York: Gotham.

Goldberg, E. (2009). The new executive brain: Frontal lobes in a complex world. New York: Oxford University Press.

Goldberg, E. (2012). «Thank you for sharing this fascinating material - very interesting». PsyAnima, Dubna Psychological Joumal, 5(1), 118-120.

Harre, R. (2006). Key thinkers in psychology. London, UK: Sage Publications.

Ivanov, V. V. (1976). Ocherki po istorii semiotiki v SSSR [Essays in history of semiotics in the USSR]. Moscow: Nauka.

Keiler, P. (2012). «Cultural-historical theory» and «Cultural-historical school»: From myth (back) to reality. PsyAnima, Dubna Psychological Joumal, 5(1), 1-33.

Kellogg, D. (2011). Untangling a genetic root of Thinking and Speech: Towards a textology of Tool and Sign in Child Development. PsyAnima, Dubna Psychological Joumal, 4(4), 85-97.

Kellogg, D., \& Yasnitsky, A. (2011). The differences between the Russian and English texts of Tool and Sign in Child Development. Supplementary and analytic materials. PsyAnima, Dubna Psychological Joumal, 4(4), 98-158.

Lewin, K. (1936). Principles of topological psychology. New York/London: McGraw-Hill Book Company.

Lück, H. (2010). Gruppovye protsessy v nauchnykh issledovaniyakh (na primere «Topologicheskoi gruppy» Kurta Levina) [Group processes in scientific research (on the example of «Topological group» of Kurt Levin]. Methodology and History of Psychology, 5(3), 77-89.

Murchison, C. (Ed.). (1931). A handbook of child psychology. Worcester, MA: Clark University Press.

Renatus (Puzyrei, A. A.). (2012). «As a matter of fact, in Vygotsky's archive only an English version of this text was initially discovered...». Dubna Psychological Journal, 1, 114-117. (in Russian)

Shchedrovitsky, G. P. (2001). Ya vsegda byl idealistom... [I've always been an idealist...]. Moscow: Put'.

Van der Veer, R. (2012). Rukopisi ne goryat or do they? PsyAnima, Dubna Psychological Joumal, 5(1), 133-138.

Van der Veer, R., \& Valsiner, J. (1991). Understanding Vygotsky: A quest for synthesis. Oxford: Blackwell.

Van der Veer, R., \& Valsiner, J. (Eds.). (1994). The Vygotsky reader. Oxford: Blackwell.

Vigotski, L. S. (1930). Le problème des fonctions intellectuelles supérieures dans le système des recherches psychotechniques. In Anals d'orientació professional (Vol. 4, pp. 332-341). Barcelona: Escola de Treball.

Vygodskaya, G. L., \& Lifanova, T. M. (1996). Lev Semenovich Vygotskii. Zhizn'. Deyatel'nost'. Shtrikhi k portretu [Lev Semenovich Vygotsky. Life. Activity. Strokes to the portrait]. Moscow: Smysl.

Vygotsky, I. S. (1930). Problema vysshikh intellektual'nykh funktsii v sisteme psikhotekhnicheskogo issledovaniya [The issue of higher intellectual functions in the system of psychotechnical research]. Psikhotekhnika i Psikhofiziologiya Truda, 3(5), 374-384.

Vygotsky, L. S. (1932/1968). Problema soznaniya [The issue of consciousness] (1932). In A. A. Leontiev \& T. V. Ryabova (Eds.), Psikhologiya grammatiki [The psychology of grammar] (pp. 178 196). Moscow: Moscow University Press.

Vygotsky, L. S. (1932/1982). Problema soznaniya [The problem of consciousness] (1932). In L. S. Vygotsky, Sobranie sochinenii [Collected works] (Vol. 1, pp. 156-166). Moscow: Pedagogika. 
Vygotsky, L. S. (1933/1966). Igra i ee rol' v psikhicheskom razvitii rebenka [Play and its role in psychic development of a child] (1933). Voprosy Psikhologii, 6, 62-76.

Vygotsky, L. S. (1934). Myshlenie i rech'. Psikhologicheskie issledovaniya [Thinking and speech. Psychological studies]. Moscow: Sotsekgiz.

Vygotsky, L. S. (1965). Psikhologiya iskusstva [The psychology of art]. Moscow: Iskusstvo.

Vygotsky, L. S. (1968). Psikhologiya iskusstva [The psychology of art] (2nd ed.). Moscow: Iskusstvo.

Vygotsky, L. S. (1978). Mind in society: the development of higher psychological processes. Cambridge: Harvard University Press.

Vygotsky, L. S. (1983). Istoriya razvitiya vysshikh psikhicheskikh funktsii [The history of development of the higher psychic functions]. In L. S. Vygotskii, Sobranie sochinenii [Collected works] (Vol. 3, pp. 5-328). Moscow: Pedagogika.

Vygotsky, L. S. (1984). Orudie i znak v razvitii rebenka [Tool and sign in the development of a child] In L. S. Vygotskii, Sobranie sochinenii [Collected works] (Vol. 6, pp. 5-90). Moscow: Pedagogika.

Vygotsky, L. S. (1984/1999). Tool and sign in the development of the child. In R. W. Rieber (Ed.), The collected works of L. S. Vygotsky (Vol. 6, pp. 3-68). New York: Plenum Press.

Vygotsky, L. S. (1994). Tool and symbol in child development. In R. Van der Veer \& J. Valsiner (Eds.), The Vygotsky reader (pp. 99-174). Cambridge, MA: Blackwell.

Yaroshevsky, M. G. (1984). Kommentarii [Commentaries]. In L. S. Vygotskii, Sobranie sochinenii [Collected works] (Vol. 6, pp. 348-356). Moscow: Pedagogika.

Yasnitsky, A. (2010). "Archival revolution" in Vygotskian Studies? Uncovering Vygotsky's archives. Joumal of the Russian and East European Psychology, 48(1), 3-13.

Yasnitsky, A. (2011a). Isolationism of Soviet psychology? The scholars, «import- export» in science, and the power. Voprosy Psikhologii, 6, 108-121. (in Russian)

Yasnitsky, A. (2011). Vygotsky Circle as a personal network of scholars: Restoring connections between people and ideas. Integrative Psychological and Behavioral Science, 45(4), 422-457.

Yasnitsky, A. (2011b). The Vygotsky that we (do not) know: Vygotsky's main works and the chronology of their composition. Dubna Psychological Joumal, 4, 53-61. Retrieved from http://psyanima.su/journal/2011/4/2011n4a1/2011n4a1.1.pdf

Yasnitsky, A. (2011c). Regarding the isolationism of the soviet psychology: Scientific publications of the 1920s and 1930s. Voprosy Psikhologii, 1, 124-136. (in Russian)

Yasnitsky, A. (2012). Revisionist revolution in Vygotskian science: Toward cultural-historical Gestalt psychology. Guest editor's introduction. Joumal of Russian and East European Psychology, 50(4), 3-14.

Yasnitsky, A. (2012b). A History of Cultural-Historical Gestalt Psychology: Vygotsky, Luria, Koffka, Lewin, and others. Dubna Psychological Joumal, 1, 98-101. Retrieved from http://psyanima.su/journal/2012/1/2012n1a2/2012n1a2.2.pdf

Yasnitsky, A. (2012a). Was there an isolationism of Soviet psychology? Unofficial personal contacts of scientists, international intermediaries and «import» of psychology. Voprosy Psikhologii, 1, 100-112. (in Russian)

Yasnitsky, A., \& Van der Veer, R. (Eds.). (2016). Revisionist revoluton in Vygotsky Studies. London/New York: Routledge.

Yasnitsky, A., Van der Veer, R., Aguilar, E., \& García, L. N. (Eds.). (2016). Vygotski revisitado: una historia crítica de su contexto y legado. Buenos Aires: Miño y Dávila Editores.

Zavershneva, E. Yu. (2008). Notebooks, notes, scientific diaries of L.S. Vygotsky: Research of the family archives. Voprosy Psikhologii, 2, 120-136. (in Russian) 
Zavershneva, E., \& Van der Veer, R. (Eds.) (2017). Zapismye knizhki L.S. Vygotskogo. Izbrannoe. [Vygotsky's notebooks: A selection]. Moscow: Kanon-plyus.

Zavershneva, E., \& Van der Veer, R. (2018). Vygotsky's notebooks: A selection. New York: Springer.

Zinchenko, V. P. (2003). «Da, ochen' protivorechivaya figura...». Zhumal Prakticheskogo Psikhologa, 1-2, $162-179$.

Anton Yasnitsky - independent researcher, Ph.D.

Research area: Vygotsky-Luria Circle; cultural-historical gestalt psychology; scientific revolutions design and management; disciplinary and transnational history of science.

E-mail: anton.yasnitsky@gmail.com 